\title{
Research on Development of Modern Service Industry in Wuhan City Circle
}

\section{Zhixiong Xiao, Yuanjian Qin}

School of Management, Wuhan University of Technology, Wuhan, China.

Email: xiaozhixiong@126.com

Received August 25 $5^{\text {th }}, 2009$; revised October 16 ${ }^{\text {th }}, 2009$; accepted November $20^{\text {th }}, 2009$.

\begin{abstract}
The modern service industry is an important force of promoting economic growth and social sustainable development. By analyzing the importance of modern service industry to the construction of "Two-oriented Society" and the advantages and disadvantages of the development of modern service industry in Wuhan City Circle, the paper presents many strategies of the development of modern service industry in Wuhan City Circle: changing concept of development, improving policies and the organizational guarantee system, accelerating industrial restructuring, clearing development ideas, strengthening market supervision, strengthening the introduction of human resources, carrying out international exchanges and cooperation.
\end{abstract}

Keywords: Wuhan City Circle, Modern Service Industry, Two-Oriented Society

\section{Introduction}

Since the 60 's in the 20th century, the global economy has shown the major trends that the industrial economy turns to the service-based economy, the proportion of service industry in GDP is increasing continuously. With the advent of the information age, in the industrial added value, the proportion of pure manufacturing sector is becoming less and less, but the proportion of modern service industry supported by information technology is more and more. According to UN statistics, from 1970 to 2002 , the services industry had accounted for $25 \%$ to $60 \%$ of entire world's stock of direct investment from foreign. While the manufacturing industry fell from $42 \%$ to $34 \%$. At present, the services industry in the Europe and the United States, particularly the knowledge-intensive modern service industry, accounts for more than half of all the services industry [1].

\subsection{The Modern Service Industry and Its Characteristics}

The modern service industry is relative to the "traditional services", is produced in a highly developed stage of the industry. The development of modern service industry is based on electronic information and modern management concepts. Its information and knowledge is relatively

This paper is sponsored by the Humanities and Social Sciences Projects Fund of Ministry of Education of China. The project number is 09YJA630125. intensive, and its essence is the modernization of modern service industry [2]. The modern service industry has four basic characteristics: 1) Intellectual. The modern service industry provides consumers with the production, dissemination and use of the knowledge and makes the knowledge achieve value-added in process of service; 2) Hi-tech. Advanced information technology and modern management concept is the basic conditions of formation and development of modern service industry; 3) High added value and clustering. Modern service industry can not only make the process of service produce the valueadded of knowledge, but also can produce the scale effect of services and agglomeration effect of integration of various services, so causes services a significant valueadded; 4) Emerging nature. The modern service industry rises from the modern, or evolves from the past in terms of time.

\subsection{The Significance of Modern Service Industry to Construction of the "Two-Oriented Society"}

The characteristics of "Two-oriented Society" are resource-saving and environment-friendly as a pattern of social development. It builds on the basis of reflection to the traditional model of economic development, is a new economic and social development model that is conducive to resource saving and environment-friendly, is a concrete manifestation of sustainable development. It requires that all aspects of economic and social devel- 
opment comply with the laws of ecology and develop in the direction of resource conservation and recycling to maintain a good ecological environment [3].

The modern service industry is a great significance to the construction and development of "Two-oriented Society" because of its characteristics. Firstly, the modern service industry helps to breakthrough the resource constrained bottleneck of the construction of "Two-oriented Society". The modern service industry is generally highknowledge and high-tech industries, such as the financial industry, consulting industry, information industry, logistics, education and training. These industries have the features of low energy consumption and high added value that are conducive to resource conservation. Secondly, the modern service industry is conducive to reducing environmental pressure of the construction of the "Two-oriented Society". Other industries of modern service industry, such as commerce, tourism, convention and exhibition industry, catering and hotel industries, have so little pollution and are conducive to achieving sustainable development.

\section{The Advantages of the Development of Modern Service Industry in Wuhan City Circle}

Wuhan City Circle is made up of Wuhan and Huangshi, Ezhou, Xiaogan, Huanggang, Xianning, Xiantao, Tianmen, Qianjiang within 100 kilometers from Wuhan. It is the regional economic consortium the center of which is Wuhan. It is the most intensive of industries and factors of production and the most dynamic region in Hubei Province, is the core of the region's economic development in Hubei Province. Wuhan City Circle was approved as a "Two-oriented Society" pilot area by the State Council and the National Development and Reform Commission in the December 14, 2007. Wuhan City Circle places emphasis on the modern service industry in the regional economic development planning building a "Two-oriented Society" as the advantages of the modern service industry in resource conservation and environmental protection. In fact, Wuhan City Circle does have many advantages to develop modern service industry.

\subsection{Policy Advantage}

Policy advantage is the biggest advantage of Wuhan City Circle. Wuhan City Circle was approved as a national-level "Two-oriented Society" pilot area and did not get the amount of direct investment from the central, the key is to obtain a pilot policy advantages, can carry out important reforms to achieve a sustainable economic and social development in the scope of policy. Furthermore, Wuhan City Circle embarks on the path of regional development by this opportunity. Wuhan City Circle will achieve economies of scale of the region development by connecting relatively independent units in circle into a complementary economic union.

\subsection{Talent Advantage}

Hubei Province has always attached much importance to science and education, talent advantages are clear. The talents of Hubei Province gather in Wuhan City Circle. There is rich in human resources, strong in science and technology, intensive in high-level talent. The comprehensive strength of science and education in Wuhan ranks the third in domestic major cities. Other cities in the circle also have a certain talent resource base. The scientific and technological human resources of Wuhan and other cities in the circle formates gradient distribution and integration trends to laid the resource base for sharing of human resources in Wuhan City Circle.

\subsection{Cultural Resources Advantage}

The cultural resources of the cities in Wuhan City Circle are rich. There are many historical and cultural attractions in Wuhan, such as Yellow Crane Tower, Panlong city, Wuchang Red Building, East Lake, Guiyuan Temple. Huangshi is the birthplace of Chinese bronze culture and has ancient copper mine sites in Tonglushan, ancient battlefields in Xisaishan, buddhist cultural sites in the East Mountain, etc.. Ezhou has the ancient capital of $\mathrm{Wu}$ King as the representative of the history landscape, Sun Quan and $\mathrm{Su}$ Shi as the representative of the cultural landscape, the Guling Temple as the representative of buddhist landscape. Huanggang has Huangmei drama, Li-Shizhen Chinese herbal medicine as the representative of non-material cultural heritage, as well as numerous cemeteries of revolutionary martyrs and the martyrs memorial. Xiaogan has a strong cultural tradition of filial piety, the story that Dongyong sold himself to bury his father is widespread. Xianning has a profound cultural background and has Chibi ancient battlefield, Tea-Horse ancient Road,etc.. The folk art in Xiantao has a long history. There are paper-cuts, shadow puppets, shell carving and other characteristics of art, besides a nationally known gymnastics town. Tianmen has $\mathrm{Lu} \mathrm{Yu}$, the ancestors of the tea ceremony and Pi Rixiu of the poet as the representative of cultural celebrities, and flower-drum drama, shadow puppets as the representative of folk art. Tianmen has also a high level of education, is nationally renowned as "the hometown of champion". Qianjiang is one of the important birthplaces of Chu Culture, there is Zhanghua-tai in the palace of Chu-ling King in Eastern Zhou, Cao $\mathrm{Yu}$ and other excellence talents. These cultural resources are conducive to the development of cultural tourism and other modern service industry.

\subsection{Natural Resources Advantage}

Wuhan City Circle is rich natural resources. Wuhan has abundant water resources. Yangtze River and Hanjiang 
River flow together in Wuhan. East Lake, the largest city lake in our country, is also in Wuhan. Huangshi has rich mineral resources, is known as "the cornucopia of Jiangnan". Ezhou has the "two lakes" (Liangzi, Red Lotus Lake) and the "Two Mountains" (Lotus Hill, Western Hills), may develop leisure tourism. Huanggang has rich agricultural and sideline native products, may be built into important regional chain distribution logistics areas. Xiaogan is rich in forest resources. Tangchi Hot Springs in yingcheng of Xiaogan city is a Well-known holiday resort. Xianning has pleasant climate and beautiful scene, is known as "yao-chi in the world". Xiantao has a flat terrain and many rivers, is rich in rivers and lakes features. Tianmen is rich in aquatic resources, salt, anhydrous Glauber's salt and oil reserves are also substantial. Qianjiang has grain, cotton, oil on ground and oil, gas and salt under ground, is the second hometown of metasequoia known as "living fossil".

\section{The Disadvantages of the Development of Modern Service Industry in Wuhan City Circle}

Wuhan City Circle has the advantage of developing modern service industry, but there is also its disadvantage.

\subsection{Low Quality Level and Small Scale of Modern Service Industry}

Modern services industry is small-scale, non-standardized, low-grade, and some have even been classified as urban environmental improvement targets. The traditional wholesale and retail trade and catering services industry accounts for a too much proportion, new services, such as information consultation, computer applications, is lack of market growth. Compared with the advanced regions and the demands of economic development, there is a wide gap. Now the service industry of most developed countries has reached $370 \%$. The service industry accounts for $70 \%$ of GDP, the employees of the service industry accounts for $70 \%$ of the employed population, $70 \%$ of economic growth comes from services industry. The proportion of modern service industry of Beijing and Shanghai in China accounts for more than $70 \%$ of GDP, as well as the proportion of modern service industry of $\mathrm{Wu}-$ han City Circle accounts only for about 50\% of GDP.

\subsection{Unbalanced Development of Modern Service Industry}

In nine cities of Wuhan City Circle, the development level of modern service industry in Wuhan is the highest and its leading position is very clear. In 2008 year, Wuhan City Circle achieves added value in services 303.894 billion yuan, in which Wuhan city achieve 198.773 billion yuan, accounts for $65.4 \%$ of city circle. From growth rate, growth rate of Wuhan is $13.5 \%$, lower than $0.7 \%$ of the average growth rate of city circle. In 9 cities $18.3 \%$ of Xianning is the highest and $10.6 \%$ of Ezhou is the lowest. From the industrial perspective, the proportion of service of only Wuhan city of nine cities is just over $50 \%$, other eight cities are lower than $40 \%$, of which there are four cities that the proportion of primary industry is higher than $20 \%$ [4].

\subsection{Lack of Unified Planning of the Development of Modern Service Industry}

Each city of city circle is aware of the importance of modern service industry to the development of society and economy, from their own interests, and has made its own development plan according to local resources conditions and levels of economic development. But the local optimum may not be able to achieve an overall optimum. Although the Wuhan City Circle is approved, there have been some good phenomena, such as the joint meeting of the mayor in 9 cities, but the form more than content, a lot of planning has still not been uniform.

\subsection{Irregular Management of Modern Service Industry}

On the hard environment side, the conditions of some earlier market can not meet the need of development and need be improved. On the soft environment side, some markets still remain chaotic management in public security, health, taxes. Illegal business around the market has seriously affected the confidence of Investors. Market owners and the relevant functional departments should reach a consensus, and further standardize and enhance the market's management level.

\section{The Development Strategy of Modern Service Industry in Wuhan City Circle}

\subsection{Changing Concept of Development}

All the cities of Wuhan City Circle should change as soon as possible the concept of development. Firstly, all the cities should establish the concept of unified planning and coordinated development, consider city circle as a whole, take full account of the resource situation and existing development advantages of each city, carry out reasonably industrial distribution, promote common development of economy and common prosperity of society in the city circle. If every city develops alone and constructs unplanned and repetitive, it will cause the waste of resources. Secondly, all the cities should establish a win-win concept of resource-saving and environment-friendly and economic development, and breakthrough backwardness development concept that things will be managed after construction. All the cities should have long-term development vision and adhere to sustainable development. 


\subsection{Improving the Policies and the Organizational Guarantee System}

The preferential policies of accelerating the development of modern service industry should be studied and formulated. The bottlenecks of structure, mechanism and talents should be breakthroughed. Government should make efforts to create the policy environment that is conducive to the rapid development of modern service industry by strengthening the macro guidance. Government should establish and improve a multi-level joint meeting, such as a joint meeting of mayors, discuss together industrial development, public facilities construction, taxation, finance, Investment, environmental protection, social management and public services, and achieve an efficient coordination of governments. Government should format Construction Management Committee of Wuhan City Circle that has certain administrative levels and powers, give and strengthen its coordination right, supervise right and implement right to overall program and a variety of special planning, and solve comprehensively the problems in the construction of Wuhan City Circle.

\subsection{Speeding Up Industrial Restructuring}

The government should scientifically make the development plan of modern service industry that is line with the actual development of Wuhan City Circle, highlight the focus of development and advance at different levels the development of modern service industry. Government should play a leading role of plan, use a means of combination of legal, administrative and market, guide resource elements to focus the emphasis areas of and regional of the modern service industry, create a distinctive industrial agglomeration area, promote the division and cooperation of modern service industry, implement differential development, optimize the layout of modern service industry of Wuhan City Circle.

\subsection{Clearing Development Ideas}

The basic idea of the development of modern service industry in Wuhan City Circle is echelon development, highlighting focal point and a difference emphasis in different cities. There is no doubt that the first echelon of echelon development is Wuhan. The second echelon is Huangshi and Ezhou. In addition to Wuhan, these two cities are the fastest cities. The third echelon is Xiantao and Qianjiang. The industry structure of these two cities is same and the development trend of industrialization is getting better. The fouth echelon is Xianning, Xiaogan, Huanggang and Tianmen. The economic strength of these four cities is weak, the level of urbanization and industrialization is not high, and the pressure of the farmers increasing income is heavy. Highlighting focal point is highlighting the core of the location and function of the Wuhan City Circle, making full use of advantages of the elements together, consolidating and developing the big traffic and big circulation to further enhance its competitiveness and radiation. A difference emphasis in different cities is that the other eight cities of Wuhan City Circle determine their own development priorities according to the actual situation. The industrial base of Huangshi, Ezhou is relatively strong, while they develop vigorously the manufacturing industry, they should also focus on the separation of the manufacturing industry and services industry, develop producer services as a breakthrough point, take new path of industrialization. The industrial development trend of Xiantao, Qianjiang is getting better, but the levels of per capita consumption is low, so they should speed up the process of industrialization, take simultaneously various measures to increase people's income and stimulate consumption, develop and expand various types of consumer services. Xianning, Xiaogan, Huanggang, Tianmen expand mainly their respective economic strengths, accept the radiation of Wuhan, do a good job of industries docking, and promote jointly the economic development of Wuhan City Circle.

\subsection{Strengthening Market Supervision}

Laws and regulations should be developed and improved, and market behavior of services industry should be standardized. Industry standards, scope of services, price fees, property management, incentives and disincentives, professional ethics, and dispute arbitration should be clearly and reasonably set. Regulation, investigation, statistics, information release system of services should be established and improved. Government should adhere to enforce strictly law, intensify efforts to rectify market order, crack down on acts of manufacturing and selling counterfeit and shoddy goods, clean-up comprehensively operation without a license, and create a fair competition environment for the development of modern service industry. The Government should also step up publicity efforts and make all sectors of society understand comprehensively the function, development planning and policy-oriented of the modern service industry.

\subsection{Intensifying the Introduction of Talent}

The Government should vigorously develop high-quality, professional service personnel, make efforts to improve the knowledge and intelligent level of the employees the modern service industry. Colleges and universities should be close to the market, found some modern service professionals, such as information services, software outsourcing, logistics, property management, finance, insurance, tourism, and foster the high-level application-oriented talents for the development of modern service industry. The Government should actively introduce high-quality services talent from domestic and abroad to venture in Wuhan City Circle and make the modern ser- 
vice industry of Wuhan City Circle integrate better with the international standards. In order to attract outstanding professional and technical personnel to join the modern service industry, the Government should allow the modern service enterprises share by the inventions, patents and proprietary technology in accordance with a certain price, and make the owner obtain the legitimate rights and interests.

\subsection{Carrying Out International Exchanges and Cooperation}

The government should continually expand the field of foreign investment, further expand the degree of openness of the telecommunications, finance, commodities, social intermediary services, tourism, etc. By delegate merchants, intermediary merchants and other international means of attracting investment, the government should attract particularly international renowned multinational headquarters, the modern service enterprises brands, develop vigorously the headquarter economy and speed up to enhance the core service functions of the city to drive the overall demand and development of modern service industry. The government should strengthen project cooperation with the government of developed countries and regions in finance, information services and other key areas to promote fully the restructuring and optimization of the modern service industry in Wuhan City Circle.

\section{Conclusions}

In a word, the strengths and weaknesses of the development of modern service industry in Wuhan City Circle exist at the same time, but the strengths are more than weaknesses. As long as all levels of government departments and enterprises seize the rare opportunities of development, make full use of preferential policies granted by the government, respect the basic laws of market development, change timely the concepts of development, select scientifically the development of strategy, the modern service industry in Wuhan City Circle will surely be a good development, the construction of "Two-oriented Society" also will be a success.

\section{REFERENCES}

[1] M. Jiang, "The center of 'Two-oriented Society': The modern service industry," Hubei Daily, 11 January 2009.

[2] Z. X. Xiao, "Situation analysis and development strategies of the modern service industry in Wuhan," Jiangsu Business Discussion, No. 2, pp. 86-88, 2009.

[3] P. Wang, "The rethinking about the connotation of 'Twooriented Society"," Northern Economy, No. 1, pp. 5-6, 2009.

[4] Wuhan Bureau of Statistics, "Analysis of service operation of Wuhan City Circle in 2008," 20 March 2009. http://www.whcc.com.cn/publish/whsww/glzt/whscsqwl/ gzjb/200903200954400040.html.http://www.conanp.gob. $\mathrm{mx} /$. 